\title{
Oprawa kaliskich druków z 1620 roku udekorowana radełkiem jagiellońskim z popiersiem kanclerza wielkiego koronnego Jana Zamoyskiego ${ }^{1}$
}

\begin{abstract}
Streszczenie. W komunikacie zaprezentowano oprawę dwóch kaliskich druków z 1620 roku, którą udekorowano za pomocą radełka jagiellońskiego z wizerunkiem kanclerza wielkiego koronnego Jana Zamoyskiego. Wolumin ten był darem Stanisława Zakrzewskiego (zm. 1631) dla Andrzeja Baranowskiego (zm. 1631), kanonika gnieźnieńskiego i krakowskiego, kantora poznańskiego, prepozyta łowickiego. Za unikatowością wymienionego narzędzia przemawia obecność wizerunku polskiego możnowładcy, niezwiązanego bezpośrednio z rodziną panującą. Niewykluczone, że przedstawiony egzemplarz został sporządzony w niezidentyfikowanej introligatorni warszawskiej. Powstał on z pewnością w przedziale od 1620 do 1631 roku, a zatem pomiędzy datą wydania druków a datą śmierci Zakrzewskiego i Baranowskiego.
\end{abstract}

Słowa kluczowe: Jan Zamoyski, Stanisław Zakrzewski, Andrzej Baranowski, Kalisz, Warszawa, introligatorstwo, tegumentologia.

W niniejszym komunikacie scharakteryzowano oprawę zabezpieczającą dwa druki z 1620 roku, które pochodzą z kaliskiej oficyny Wojciecha

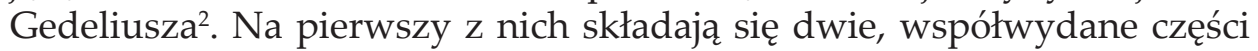
pierwszego tomu Orationum ecclesiasticarum dominicalium, który wyszedł spod pióra kanonika regularnego i kaznodziei przy kościele św. Jerzego

1 Praca powstała w ramach projektu grantowego: „Inwentaryzacja zasobu Archiwum Archidiecezjalnego w Gnieźnie: starodruki z Kolekcji Seminaryjnej Biblioteki Katedralnej i nowoodnalezione dokumenty papierowe konsystorza gnieźnieńskiego z XV i pocz. XVI w.", finansowanego z Narodowego Programu Rozwoju Humanistyki MNiSW (11H 160124 84), kierownik: dr hab. Piotr Pokora (Instytut Historii UAM w Poznaniu).

2 Archiwum Archidiecezjalne w Gnieźnie (dalej: AAG), sygn. BK 4853. 
w Warszawie Stanisława Zakrzewskiego (zm. 1631)3. Omawiane dzieło zostało dedykowane królowi Zygmuntowi III Wazie, prymasowi i arcybiskupowi gnieźnieńskiemu Wawrzyńcowi Gembickiemu oraz opatowi czerwińskiemu i biskupowi chełmskiemu Jerzemu Zamoyskiemu4. Wolumin zamyka Iosephus patriarcha seu oratio ecclesiastica de b. Ignatio fundatore Societatis Iesu tego samego autora ${ }^{5}$. Ten przeszło trzydziestostronicowy druczek dedykowano z kolei Albrychtowi Stanisławowi Radziwiłłowi. Stronę tytułową pierwszego z dzieł opatrzono dwoma wpisami własnościowymi. Starszy z nich, uczyniony najpewniej ręką samego Zakrzewskiego, wskazuje na pierwotnego posiadacza książki: „Magnifico et Admodu[m] R[evere]ndo in Ch[rist]o P[at]r[is] D[omi]no D[omi]no Baranowski Praeposito Lovicien[si] S.R.M.S. eximia p[ate]r[n]itate, summa eruditione, maxima humanitate, celeber[r]im[o] D[o]m[ino] Suo et Patrono Author offert" ${ }^{\prime \prime}$. Był nim bratanek zmarłego w 1615 roku prymasa Wojciecha Baranowskiego - Andrzej (zm. 1631), kanonik gnieźnieński i krakowski, kantor poznański, prepozyt łowicki . Druga z proweniencji: „Eccl[esi]ae Metrop[olitanae] Gnesn[ensis]” informuje o późniejszej przynależności woluminu do zbiorów gnieźnieńskiej kapituły katedralnej.

Oprawa omawianego egzemplarza została wykonana z tektury, którą powleczono ciemnobrązową skórą. Blok książki scalają trzy zwięzy sznurowe tworzące na grzbiecie niewielkie garby. Przy dłuższych brzegach każdej z okładzin znajdowała się pierwotnie para tasiemek. Zdobienia oprawy, sporządzone $\mathrm{w}$ technice ślepego i złoconego wycisku (tłoczenia), opracowano za pomocą: strychulca, dwóch radełek, plakiety oraz trzech łłoków z motywami floralnymi. Dekorację okładzin (il. 1 i 2 ) oparto na jednakowo rozplanowanej kompozycji. Składa się ona z zewnętrznej

3 K. Estreicher, Bibliografia polska, t. 34, Kraków 2000, s. 114; K. Bielska, Bibliografia starych druków kaliskich. Do końca XVIII w., Warszawa-Poznań 1980, nr 65; na temat Stanisława Zakrzewskiego zob. np. M. Gębarowicz, Jan Andrzej Próchnicki (1553-1633). Mecenas i bibliofil. Szkic z dziejów kultury w epoce kontrreformacji, Kraków 1980, s. 163.

4 Karta z dedykacją dla Jerzego Zamoyskiego została w omawianym egzemplarzu wycięta.

5 K. Estreicher, op.cit., s. 114; K. Bielska, op.cit., nr 64.

6 Chciałbym złożyć podziękowania mgr. Jakubowi Łukaszewskiemu za pomoc w poprawnym odczytaniu wpisu własnościowego. Wyrazy wdzięczności za wszelkie wsparcie niech zechce przyjąć również mgr Radosław Franczak.

7 L. Łętowski, Katalog biskupów, prałatów i kanoników krakowskich. Prałaci i kanonicy krakowscy, t. 2, Kraków 1852, s. 10-11; J. Korytkowski, Prataci i kanonicy katedry metropolitalnej gnieźnieńskiej od roku 1000 aż do dni naszych. Podług źródeł archiwalnych, t. 1, Gniezno 1883, s. 29-30; H. Barycz, Marcantonio Bonciario i Polacy. Karta z dziejów kulturalnych polsko-włoskich w XVII wieku, w: Munera litteraria. Księga ku czci profesora Romana Pollaka, red. W. Dworzaczek et al., Poznań 1962, s. 20. 
Il. 1. Oprawa starodruków z 1620 roku - górna okładzina, introligator anonimowy, Warszawa (?), 1620-1631 Źródło: Archiwum Archidiecezjalne w Gnieźnie, fot. Michał Muraszko.
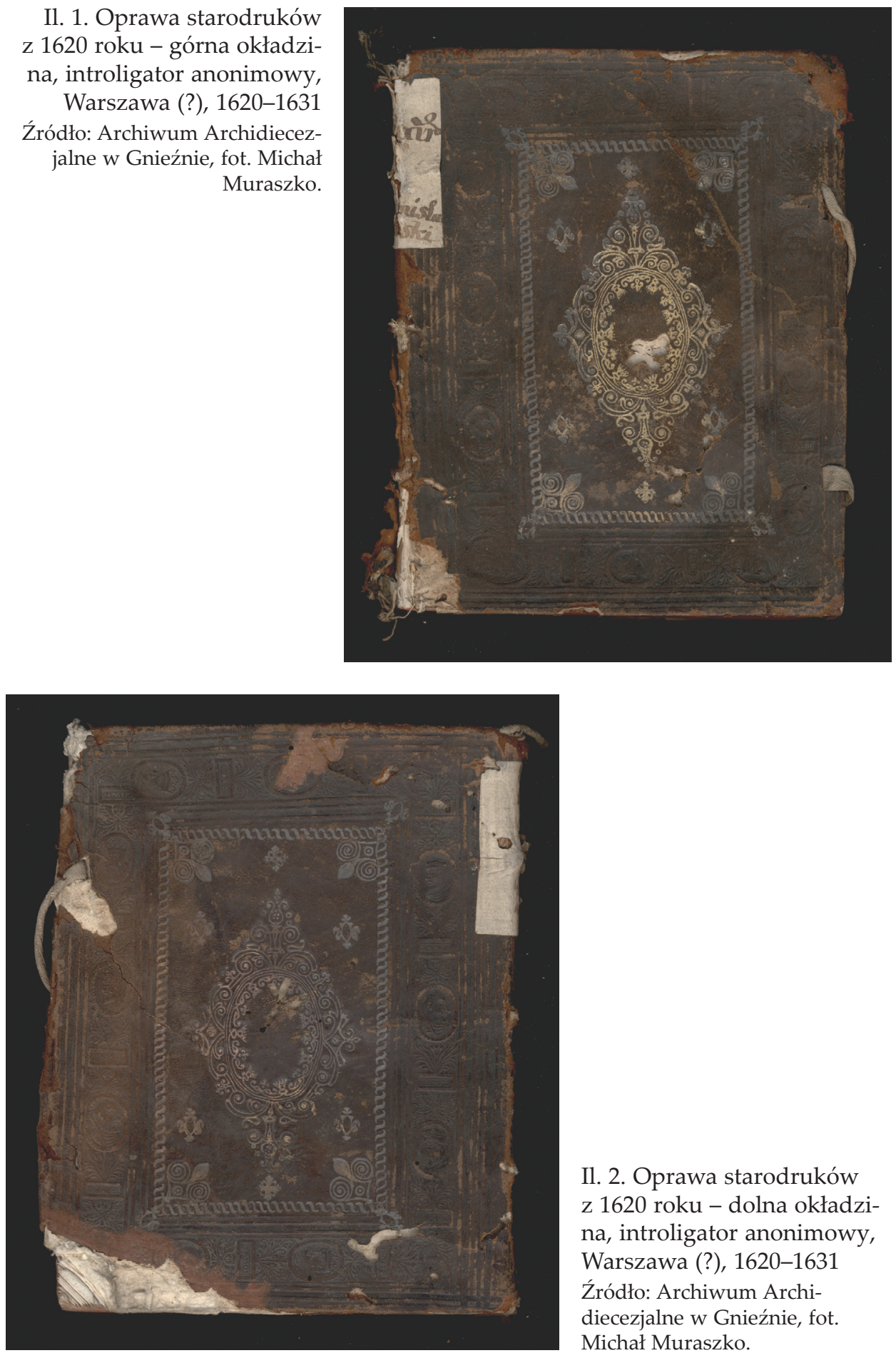

Il. 2. Oprawa starodruków z 1620 roku - dolna okładzina, introligator anonimowy, Warszawa (?), 1620-1631 Źródło: Archiwum Archidiecezjalne w Gnieźnie, fot. Michał Muraszko. 

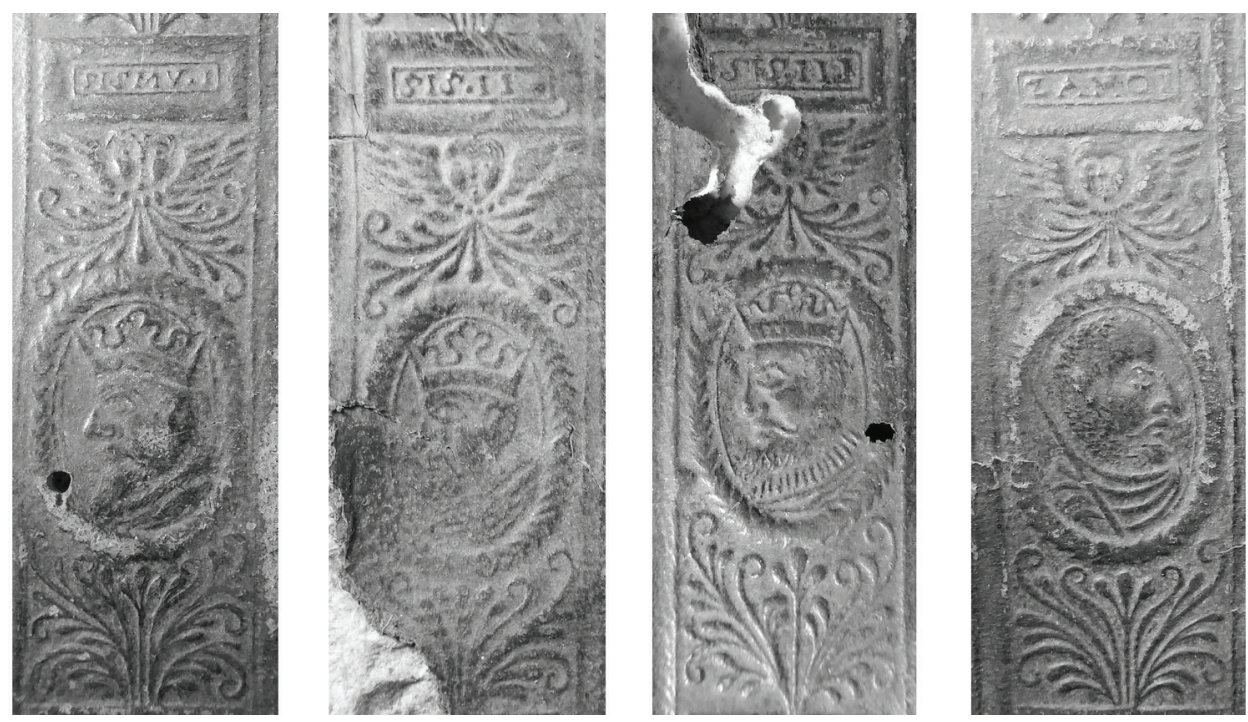

Il. 3. Fragmenty wycisków radełka jagiellońskiego z popiersiami Zygmunta I Starego, Zygmunta II Augusta, Zygmunta III Wazy oraz Jana Zamoyskiego na oprawie starodruków z 1620 roku, introligator anonimowy, Warszawa (?), 1620-1631

Źródło: Archiwum Archidiecezjalne w Gnieźnie, fot. Michał Muraszko.

ramy, w którą wkomponowano ślepe wyciski tzw. radełka jagiellońskie$\mathrm{go}^{8}$. Przedstawiają one popiersia profilowe trzech polskich monarchów oraz kanclerza wielkiego koronnego Jana Zamoyskiego (il. 3). Medaliony, ujęte w laurowe wieńce, rozgranicza ornament roślinny i motywy uskrzydlonych główek anielskich. Powyżej wyobrażeń znajdują się prostokątne ramki z napisami identyfikacyjnymi. Konterfekty Zygmunta

8 Zob. np. M. Jarosławiecka-Gąsiorowska, Ikonografia świecka na oprawach XVI i XVII w., „Rocznik Biblioteki Narodowej” 1970, t. 6, s. 323-336; eadem, Radełka jagiellońskie, w: Encyklopedia wiedzy o ksiązce, Wrocław 1971, kol. 2048-2049; B. Trelińska, Portrety jagiellońskie na oprawach starodruków z Wojewódzkiej Biblioteki Publicznej im. Hieronima Łopacińskiego w Lublinie, w: Książki i Historia. Księga Jubileuszowa ofiarowana dr. Zdzistawowi Bieleniowi z okazji 50-lecia nieprzerwanej pracy w Bibliotece im. Hieronima Łopacinskiego w Lublinie, Lublin 2008, s. 119-124; A. Wagner, Radełka jagiellońskie - fenomen introligatorstwa polskiego XVI-XVII w., „Spotkania z Zabytkami” 2010, t. 5-6, s. 70-71; K. Płaszczyńska, Dekoracja opraw skórzanych XVI-XVII w. - figuracyjne motywy na radełkach (na przykładzie opraw z Biblioteki Księży Misjonarzy w Krakowie), w: Problemy edytorstwa, bibliologii i typografii, red. A. Ptak, K. Baran, Lublin 2011, s. 278-281; A. Wagner, Poznańskie radełko jagiellońskie z lat czterdziestych XVI wieku. Problem treści ideowo-politycznych i wzorów ikonograficznych, "Roczniki Biblioteczne” 2012, t. 56, s. 83-111; R. Franczak, Oprawa Homiliarum z petnopostaciowym wyciskiem radełka jagiellońskiego w zbiorach Archiwum Archidiecezjalnego w Gnieźnie, „Biblioteka” 2016, nr 29, s. 55-69; M. Muraszko, Poznańska oprawa ozdobiona tzw. radełkiem jagiellońskim z wizerunkiem króla Henryka Walezego, „Iluminacje. Kwartalnik o iluminowanych manuskryptach” 2016, t. 12 , s. $22-25$. 
I Starego (SISMV. I), jego syna - Zygmunta II Augusta (SIS. II.) oraz wnuka - Zygmunta III Wazy (SIS. III) ukazano w lewym profilu. Posiadają oni długie brody oraz korony na głowach, natomiast Zygmunt III ma pod szyją krezę . Jan Zamoyski (ZAMOI) został z kolei przedstawiony $\mathrm{w}$ prawym profilu. Kanclerz ma wysokie czoło oraz krótko przystrzyżoną brodę i wąsy. Ubrany jest w drapowaną szatę lub płytową zbroję. Na jego prawym ramieniu opiera się regiment lub buława ${ }^{10}$. Pozostałe elementy dekoracji okładzin wykonano w technice wycisku złoconego. Wewnętrzne ramy sporządzono za pomocą radełka $\mathrm{z}$ ornamentem plecionkowym. Centrum każdego z utworzonych w ten sposób prostokątnych zwierciadeł ozdobiono natomiast owalnym medalionem $\mathrm{z}$ lambrekinem $\mathrm{w}$ filigranowym - niemal jubilerskim - obramieniu ${ }^{11}$. Całość kompozycji dopełniają regularnie rozmieszczone wyciski z trzech tłoków o motywach floralnych ${ }^{12}$.

Przedstawioną wyżej dekorację radełka jagiellońskiego charakteryzuje daleko posunięte uproszczenie formy, zahaczające wręcz o prymitywizm. Popiersia królów oraz kanclerza, ukazane w skonwencjonalizowany sposób, są niemal pozbawione indywidualizujących je cech. Nie mogą się one równać z kunsztownie opracowanymi wyobrażeniami, które pojawiają się na innych tego typu narzędziach introligatorskich. Zdarzało się, że rytownicy, chcąc jak najwierniej odtworzyć fizjonomie poszczególnych postaci, sięgali bezpośrednio po wzorce $\mathrm{w}$ postaci medali, monet czy rycin z ich wizerunkami. Warto przytoczyć w tym miejscu przykład poznańskiego radełka jagiellońskiego z popiersiami Zygmunta Starego, Zygmunta Augusta, Pawła III, Karola V oraz Ferdynanda I, któremu odrębne studium poświęcił Arkadiusz Wagner ${ }^{13}$. Inny dobry przykład

9 Zob. M. Jarosławiecka-Gąsiorowska, Ikonografia świecka..., s. 336.

${ }^{10} \mathrm{Na}$ temat dawnych przedstawień Jana Zamoyskiego zob. np. I. Winiewicz-Cybulska, Z ikonografii Jana Zamoyskiego - cz. I, "Zamojski Kwartalnik Kulturalny” 2005, t. 82-83, s. $102-108$.

11 A. Wagner, Superekslibris polski. Studium o kulturze bibliofilskiej i sztuce od średniowiecza do połowy XVII wieku, Toruń 2016, s. 405 oraz il. 186; zob. także E. Laucevičius, XV-XVIII a. knygu irišimai Lietuvos bibliotekose, Vilnius 1976, il. 571.

${ }^{12}$ Stan zachowania oprawy nie jest zadowalający. Znacznemu uszkodzeniu uległy bowiem grzbiet woluminu oraz lico skóry pokrywającej okładziny. Co więcej, w tych ostatnich występują otwory będące pozostałością po żerowaniu owadów. Nieco gorzej prezentuje się przy tym okładzina dolna, która dodatkowo została pozbawiona znacznego fragmentu jednego z narożników.

13 A. Wagner, Poznańskie radełko..., s. 83-111; warto odnotować, że w trakcie wspomnianych prac inwentaryzacyjnych prowadzonych w zbiorach AAG natrafiono na trzy woluminy (sygn.: BK 863; BK 873; BS 2562), których oprawy udekorowano tym narzędziem; por. P. Pokora, M. Muraszko, Skarby drukarstwa i introligatorstwa ze zbiorów dawnej 
drobiazgowego opracowania stanowić mogą dwa unikatowe radełka z portretami Henryka Walezego ${ }^{14}$.

Za wyjątkowością narzędzia będącego przedmiotem niniejszych rozważań przemawia zatem nie jego artyzm, lecz obecność podobizny Jana Zamoyskiego. Maria Jarosławiecka-Gąsiorowska w opublikowanym już przed bez mała 50 laty artykule Ikonografia świecka na oprawach XVI $i$ XVII w. stwierdziła: "dotychczas nie znamy na oprawach - wizerunków żadnych innych osób świeckich z Polską związanych poza rodziną królewską"15. Wydaje się, że omawiane radełko należy uznać za drugi zidentyfikowany obecnie tłok introligatorski z konterfektem lokalnego możnowładcy ${ }^{16}$. Prawdopodobnie powstało ono jeszcze za życia Zamoyskiego, a zatem najpóźniej w 1605 roku. Umieszczenie jego popiersia $\mathrm{w}$ towarzystwie trzech monarchów świadczy z pewnością o znaczeniu oraz estymie, jaką cieszył się kanclerz. Należy przy tym pamiętać o królewskich aspiracjach tego ostatniego po śmierci Stefana Batorego oraz pierwszoplanowej roli, jaką odgrywał w początkowym okresie panowania jego następcy ${ }^{17}$. Radełko mogło zostać sporządzone w kręgu zwolenników Zamoyskiego oraz stanowić element propagandy, mający wspierać ambicje dostojnika. Warto przy tym zauważyć, że twórca prezentowanego narzędzia pominął w przekazie ikonograficznym postać Batorego. Niewykluczone, że zestawienie dwóch ostatnich Jagiellonów oraz Zygmunta III Wazy miało na celu podkreślenie pochodzenia tego

Biblioteki Katedralnej w Gnieźnie. Katalog wystawy w Bibliotece Raczyńskich, Poznań 5-30 maja 2015, Poznań-Gniezno 2015, s. 11; zob. także J. Rył, Archiwum i biblioteka w katedrze gnieźnieńskiej, Gniezno 1994, s. 47, fot. 29.

14 Zob. M. Jarosławiecka-Gąsiorowska, Ikonografia świecka..., s. 335; M. Muraszko, Poznańska oprawa..., s. 22-25.

${ }^{15}$ M. Jarosławiecka-Gąsiorowska, Ikonografia świecka..., s. 337.

${ }^{16}$ Przykład innego radełka jagiellońskiego z wizerunkiem Zamoyskiego przytaczają Sten G. Lindberg (Reliures polonaises dans les Bibliotheques suedoises de l'age gothique, de la Renaissance et de la Reforme, w: VIIIe Congrès International des Bibliophiles. Varsovie, 23-29 juillet 1973, red. K. Dymkowska, J. Pasztaleniec-Jarzyńska, Varsovie 1985, s. 105) oraz Jakub Zdzisław Lichański (Oprawy ksiażek ze zbiorów Biblioteki Collegium Societatis Iesu w Braniewie. Wstęp do badań, "Rocznik Biblioteki Narodowej” 2006, t. 37-38, s. 228 oraz il. 9b, s. 235). Popiersie możnowładcy, opatrzone podpisem „KANC”, jest łudząco podobne do tego, które omówiono w niniejszym komunikacie. Niewykluczone, że oba narzędzia wyszły spod ręki tego samego rzemieślnika. Jeśli tak się nie stało, twórca późniejszego z nich mógł wzorować się na starszym lub też odwołano się przy ich sporządzeniu do wspólnego wzoru. Za zwrócenie uwagi na to radełko składam podziękowanie mgr. Michałowi Bartoszakowi; zob. także Biblioteka Jagiellońska (dalej: BJ), sygn. Teol. 5328.

17 Zob. np. M. Markiewicz, Historia Polski 1492-1795, Kraków 2002, s. 416; S. Leśniewski, Jan Zamoyski hetman i polityk, Warszawa 2008, s. 97-98. 
ostatniego, a co za tym idzie jego związku z wygasłą w linii męskiej dynastią Jagiellonów ${ }^{18}$. Był on przecież synem Katarzyny - najmłodszej córki Zygmunta I Starego.

Jak już wspomniałem, druki, które zabezpiecza zaprezentowana oprawa, zostały wydane w Kaliszu. Nie tam jednak należy szukać introligatorni posługującej się radełkiem z profilowym popiersiem Jana Zamoyskiego. Przesłankę pozwalającą na identyfikację ośrodka, w którym mogła być ona zlokalizowana, dostarcza inna księga, należąca niegdyś do księgozbioru krakowskich augustianów, której okładziny ozdobiono wymienionym narzędziem. Zawiera ona dzieło Dictionum latinarum et graecarum interpres autorstwa Ambrożego Calepinusa. Ukazało się ono w 1521 roku w Hagenau. Zabytek ten przechowywany jest obecnie w Bibliotece Jagiellońskiej w Krakowie pod sygnaturą: Aug. 1017019. Jego oprawa została sporządzona z fazowanych desek, które powleczono jasną skórą i wyposażono w zapięcia mosiężno-skórzane. Wolumin zszyto na cztery zwięzy, a ich garby wyznaczono liniami strychulcowymi, tworząc wyzbyte zdobień kompartymenty. Dekorację omawianego egzemplarza opracowano w technice ślepego i złoconego wycisku, przy wykorzystaniu m.in. strychulca, trzech radełek oraz plakiety. Na zdobienia górnej okładziny oprawy składają się trzy koncentryczne ramy, w których umieszczono ślepe wyciski radełek z popiersiem Jana Zamoyskiego oraz ornamentem palmetowo-arkadowym, a także złoconym ornamentem plecionkowym. W górnej strefie tej okładziny wkomponowano złocony napis: "AMBROSII CALEPINI". Natomiast w centrum prostokątnego zwierciadła ukazano medalion z monogramem IHS, który został wyciśnięty złotem z plakiety na papierowej, barwionej na czerwono podkład$\mathrm{ce}^{20}$. Wewnętrzne narożniki zwierciadła zdobi z kolei złocony motyw uskrzydlonej główki anielskiej. Całość dopełniają wyciski z trzech tłoków floralnych. Dekoracja dolnej okładziny opisywanego woluminu opiera się na zbliżonej kompozycji ramowej. Została ona opracowana w całości $\mathrm{w}$ technice ślepego wycisku. Zwierciadło tej okładziny wypełniają

18 B. Trelińska, op.cit., s. 124.

${ }^{19}$ Catalogus librorum saeculi XVI qui in Bibliotheca Iagellonica Cracoviensis asservantur. BJ 16, t. 2, red. M. Malicki, Baden-Baden 2002, s. 141-142, nr C-91; ołówkowy przerys wycisków radełka jagiellońskiego na tej oprawie wykonała Anna Lewicka-Kamińska; zob. BJ, sygn. Przyb. 136/80. Badaczka nie łączyła omawianego narzędzia z Małopolską. Informuje o tym tytuł teczki, w której znajduje się wskazany przerys: „Polska (bez Krakowa). T. 1: Lwów, Przemyśl, Litwa". Niewykluczone, że przedstawiane radełko zostało sporządzone w domenie Zamoyskiego oraz było tam pierwotnie wykorzystywane do celów propagandowych. Inne przerysy Lewickiej-Kamińskiej, na których znajdują się wyciski dwóch radełek z popiersiami kanclerza, znaleźć można w teczce „Wilno” (BJ, sygn. Przyb. 120/80).

${ }^{20}$ Zob. A. Wagner, Superekslibris polski..., s. 471-472. 
trzy pionowe pasy wykonane za pomocą omawianego radełka jagiellońskiego. Można przypuszczać, że przedstawiana oprawa powstała na przełomie XVI i XVII stulecia. Druk z 1521 roku, który ona zabezpiecza, poddano wówczas zabiegom konserwatorskim. Zdefektowane karty podklejono fragmentami papieru. Miejsca, w których edycja została wyzbyta całych stronic, uzupełniono natomiast czystymi kartami. Znajdujący się na nich znak wodny ${ }^{21}$ przedstawia herb Topór w ozdobnym kartuszu z orłem w klejnocie. Filigran ten łączy się z jednym z młynów małopolskich (Tęczynek/Krzeszowice?) ${ }^{22}$. Możliwe, że twórca przedstawianej oprawy sięgnął po papier lokalnej proweniencji ${ }^{23}$. W takiej sytuacji poszukiwaną introligatornię należałoby ulokować w Małopolsce, może w samym Krakowie. W drugiej dekadzie XVII stulecia opisywane radełko jagiellońskie znajdowało się najpewniej w jednej z pracowni warszawskich. Wydaje się bowiem, że za jego pomocą udekorowano przynajmniej trzy księgi Metryki Koronnej ${ }^{24}$. Warto w tym miejscu przypomnieć, że Stanisław Zakrzewski, domniemany zleceniodawca oprawienia woluminu, był związany z nową stolicą przez pełnienie funkcji kaznodziei przy kościele św. Jerzego.

Wydaje się, że radełko jagiellońskie, które jest przedmiotem tej analizy, wyszło spod ręki niewprawnego rytownika oraz było prawdopodobnie używane w bliżej niezidentyfikowanym warsztacie małopolskim, a następnie $w$ jednej $z$ introligatorni warszawskich. Za jego unikatowością przemawia obecność wizerunku polskiego możnowładcy. Towarzyszący trzem monarchom Zamoyski został uhonorowany w sposób mający $w$ rodzimym introligatorstwie chyba jedyną znaną obecnie analogię.

${ }^{21}$ Wymieniony filigran znajduje się również przynajmniej na przedniej wyklejce woluminu.

${ }^{22}$ Por. J. Siniarska-Czaplicka, Filigrany papierni położonych na obszarze Rzeczypospolitej Polskiej od poczatku XVI do połowy XVIII wieku, Wrocław 1969, s. 19 oraz nr 1126 (zbliżony filigran); zob. także eadem, Papier druków tłoczonych na ziemiach województw krakowskiego i sandomierskiego w latach 1550-1700, „Kwartalnik Historii Kultury Materialnej” 1976, t. 24, nr 2, s. 267, nr 10 oraz s. 268.

${ }^{23}$ Zob. np. A. Wagner, Introligatorstwo poznańskie XVI wieku jako historyczno-artystyczna "terra incognita", w: Sztuka w Wielkopolsce, red. M. Błaszczyński et al., Poznań 2013, s. 71; M. Pronobis-Gajdzis, Niewidoczne dla oczu. Przyczynek konserwatora - restauratora ksiażki do badań tegumentologicznych, w: Tegumentologia polska dzisiaj, red. A. Wagner, Toruń 2015, s. 348,350 .

${ }^{24}$ Archiwum Główne Akt Dawnych, sygn.: MK 156; MK 167; MK 168 (oprawy znam z fotografii); o przewiezieniu Metryki Koronnej z Krakowa do Warszawy w końcu XVI wieku zob. np. W. Krawczuk, Metryka Koronna i Metryka Litewska, w: Dyplomatyka staropolska, red. T. Jurek, Warszawa 2015, s. 194. Składam podziękowania mgr. Michałowi Bartoszakowi za zwrócenie uwagi na wyszczególnione oprawy. 
Niewykluczone, że gnieźnieński egzemplarz, będący przecież darem Stanisława Zakrzewskiego dla Andrzeja Baranowskiego, trafił do tego ostatniego już oprawiony. Musiało to nastąpić z pewnością między 1620 a 1631 rokiem. Rodzi się też pytanie, czy wykorzystanie wskazanego narzędzia do udekorowania okładzin książki stanowiło wyłącznie przejaw panującej wówczas mody, czy może stała za nim również chęć nawiązania do postaci zmarłego nie tak dawno kanclerza ${ }^{25}$. Wydaje się jednak, że użycie ideowo zdezaktualizowanego już od przynajmniej kilkunastu lat radełka należy rozpatrywać jako jedną z wielu oznak przypadającego na pierwszą połowę XVII wieku kryzysu rodzimego introligatorstwa.

\section{Bibliografia}

Źródła

Archiwum Archidiecezjalne w Gnieźnie, sygn.: BK 863; BK 873; BK 4853; BS 2562. Archiwum Główne Akt Dawnych, sygn.: MK 156; MK 167; MK 168.

Biblioteka Jagiellońska, sygn.: Aug. 10170; Przyb. 136/80; Przyb. 120/80; Teol. 5328.

Literatura

Barycz H., Marcantonio Bonciario i Polacy. Karta z dziejów kulturalnych polsko-włoskich w XVII wieku, w: Munera litteraria. Ksiega ku czci profesora Romana Pollaka, red. W. Dworzaczek et al., Poznań: PWN 1962.

Bielska K., Bibliografia starych druków kaliskich. Do końca XVIII w., Warszawa-Poznań: PWN 1980.

Catalogus librorum saeculi XVI qui in Bibliotheca Iagellonica Cracoviensis asservantur. BJ 16, t. 2, red. M. Malicki, Baden-Baden: Valentin Koerner 2002.

Estreicher K., Bibliografia polska, t. 34, Kraków: Wydawnictwo Uniwersytetu Jagiellońskiego 2000.

Franczak R., Oprawa Homiliarum z petnopostaciowym wyciskiem radełka jagiellońskiego w zbiorach Archiwum Archidiecezjalnego w Gnieźnie, „Biblioteka” 2016, nr 29.

Gębarowicz M., Jan Andrzej Próchnicki (1553-1633). Mecenas i bibliofil. Szkic z dziejów kultury w epoce kontrreformacji, Kraków: Społeczny Instytut Wydawniczy Znak 1980.

Jarosławiecka-Gąsiorowska M., Ikonografia świecka na oprawach XVI i XVII w., „Rocznik Biblioteki Narodowej” 1970, t. 6.

Jarosławiecka-Gąsiorowska M., Radetka jagiellońskie, w: Encyklopedia wiedzy o ksiażce, Wrocław: Zakład Narodowy im. Ossolińskich 1971.

Korytkowski J., Prałaci i kanonicy katedry metropolitalnej gnieźnieńskiej od roku 1000 aż do dni naszych. Podług źródeł archiwalnych, t. 1, Gniezno: Nakładem i drukiem J.B. Langiego 1883.

${ }^{25}$ Por. A. Wagner, Radełka jagiellońskie..., s. 71. 
Krawczuk W., Metryka Koronna i Metryka Litewska, w: Dyplomatyka staropolska, red. T. Jurek, Warszawa: Wydawnictwo DiG 2015.

Laucevičius E., XV-XVIII a. knygu irišimai Lietuvos bibliotekose, Vilnius: Mokslas 1976.

Leśniewski S., Jan Zamoyski hetman i polityk, Warszawa: Bellona 2008.

Lichański J.Z., Oprawy książek ze zbiorów Biblioteki Collegium Societatis Iesu w Braniewie. Wstęp do badań, "Rocznik Biblioteki Narodowej” 2006, t. 37-38.

Lindberg S.G., Reliures polonaises dans les Bibliotheques suedoises de l'age gothique, de la Renaissance et de la Reforme, w: VIIIe Congrès International des Bibliophiles. Varsovie, 23-29 juillet 1973, red. K. Dymkowska, J. Pasztaleniec-Jarzyńska, Varsovie: Bibliotheque nationale 1985.

Łętowski L., Katalog biskupów, prałatów i kanoników krakowskich. Prałaci i kanonicy krakowscy, t. 2, Kraków: Drukarnia Uniwersytetu Jagiellońskiego 1852.

Markiewicz M., Historia Polski 1492-1795, Kraków: Wydawnictwo Literackie 2002.

Muraszko M., Poznańska oprawa ozdobiona tzw. radełkiem jagiellońskim z wizerunkiem króla Henryka Walezego, „Iluminacje. Kwartalnik o iluminowanych manuskryptach" 2016, t. 12.

Płaszczyńska K., Dekoracja opraw skórzanych XVI-XVII w. - figuracyjne motywy na radełkach (na przykładzie opraw z Biblioteki Księży Misjonarzy w Krakowie), w: Problemy edytorstwa, bibliologii i typografii, red. A. Ptak, K. Baran, Lublin: Wydawnictwo KUL 2011.

Pokora P., Muraszko M., Skarby drukarstwa i introligatorstwa ze zbiorów dawnej Biblioteki Katedralnej w Gnieźnie. Katalog wystawy w Bibliotece Raczyńskich, Poznań 5-30 maja 2015, Poznań-Gniezno: Instytut Historii UAM 2015.

Pronobis-Gajdzis M., Niewidoczne dla oczu. Przyczynek konserwatora - restauratora książki do badań tegumentologicznych, w: Tegumentologia polska dzisiaj, red. A. Wagner, Toruń: Wydawnictwo Naukowe Uniwersytetu Mikołaja Kopernika 2015.

Rył J., Archiwum i biblioteka w katedrze gnieźnieńskiej, Gniezno: Gaudentinum 1994.

Siniarska-Czaplicka J., Filigrany papierni położonych na obszarze Rzeczypospolitej Polskiej od poczatku XVI do połowy XVIII wieku, Wrocław: Zakład Narodowy im. Ossolińskich - Wydawnictwo PAN 1969.

Siniarska-Czaplicka J., Papier druków tłoczonych na ziemiach województw krakowskiego i sandomierskiego w latach 1550-1700, „Kwartalnik Historii Kultury Materialnej" 1976, t. 24, nr 2.

Trelińska B., Portrety jagiellońskie na oprawach starodruków z Wojewódzkiej Biblioteki Publicznej im. Hieronima Łopacińskiego w Lublinie, w: Książi i Historia. Księga Jubileuszowa ofiarowana dr. Zdzisławowi Bieleniowi z okazji 50-lecia nieprzerwanej pracy w Bibliotece im. Hieronima Łopacińskiego w Lublinie, Lublin: Wojewódzka Biblioteka Publiczna im. Hieronima Łopacińskiego 2008.

Wagner A., Introligatorstwo poznańskie XVI wieku jako historyczno-artystyczna "terra incognita", w: Sztuka w Wielkopolsce, red. M. Błaszczyński et al., Poznań: Wydawnictwo Nauka i Innowacje 2013.

Wagner A., Poznańskie radełko jagiellońskie z lat czterdziestych XVI wieku. Problem treści ideowo-politycznych i wzorów ikonograficznych, "Roczniki Biblioteczne" 2012 , t. 56. 
Wagner A., Radełka jagiellońskie - fenomen introligatorstwa polskiego XVI-XVII w., "Spotkania z Zabytkami" 2010, t. 5-6.

Wagner A., Superekslibris polski. Studium o kulturze bibliofilskiej i sztuce od średniowiecza do połowy XVII wieku, Toruń: Wydawnictwo Naukowe Uniwersytetu Mikołaja Kopernika 2016.

Winiewicz-Cybulska I., Z ikonografii Jana Zamoyskiego - cz. I, „Zamojski Kwartalnik Kulturalny" 2005, t. 82-83.

\author{
MICHAє MURASZKO
}

\title{
The binding of Kalisz prints of 1620 embelli- shed by the so-called "Jagiellonian finishing roll" bearing a bust of Jan Zamoyski, Lord Grand-Chan- cellor of the Crown
}

\begin{abstract}
This article presents the binding of two Kalisz prints from 1620 that has been embellished by the so-called Jagiellonian finishing roll bearing the image of Jan Zamoyski, Lord Grand-Chancellor of the Crown. This particular volume was a gift from Stanisław Zakrzewski (d. 1631) to Andrzej Baranowski (d. 1631), a Gniezno and Cracow canon, Poznań precentor and Łowicz provost. The very image of a Polish magnate, not directly related to the ruling family, demonstrates a particular uniqueness of the implemented tool. It might have been so that the presented copy had been made in an unidentified bindery in Warsaw. It certainly originated between 1620 and 1631, therefore before the date of the prints' publishing date and the date of the deaths of both Zakrzewski and Baranowski.
\end{abstract}

Keywords: Jan Zamoyski, Stanisław Zakrzewski, Andrzej Baranowski, Kalisz, Warszawa, book bindery, bookbinding studies. 
